\title{
An Examination of Chronology, Ethnic Group, and Social Ranking Based on Mortuary Data from Central Korea
}

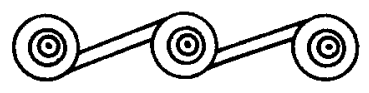

BONG WON KANG

\section{INTRODUCTION}

From December 1997 through April 1998, Kyung Hee University Museum, Seoul, conducted an extensive archaeological excavation at Hageori, Yeoju, in central Korea (Fig. 1). The project came about because of the construction of a public golf course that was part of a government-funded recreation program. It was necessary under Korean cultural properties protection law to excavate and salvage the archaeological resources in the project area because it was anticipated that they would be destroyed by the golf course construction.

The Hageori site is located some $70 \mathrm{~km}$ southeast of Seoul and $13 \mathrm{~km}$ from the center of Yeoju (see Fig. 1). Japanese prehistorians initiated archaeological excavations of burials in Yeoju from as early as the 1910s. After that, Yeoju did not receive much attention until the 1970s, when archaeologists from Seoul National University Museum conducted a large-scale excavation at the Hunamni site, where they uncovered many Korean Bronze Age (dated to c. 1000-300 B.c.) pit houses. It was expected that many archaeological remains would be found because Yeoju is relatively close to Hanseong (present-day Seoul), the capital of the Baekje Kingdom and has good environmental conditions for human habitation in terms of a permanent water source and abundant arable land. A few field surveys have been conducted and the presence of many stone-chamber tombs has been reported (Choi et al. 1988, 1989; Kim et al. 1986). In addition, a few small archaeological excavation projects on burials have been conducted in Yeoju over the years (Choi et al. 1988, 1989).

By the time the Kyung Hee University Museum excavation team arrived at the site, the majority, if not all, of the burials had been either looted or severely disturbed by erosion and/or the agricultural practices of local farmers. A total of 63 burials were uncovered at the site, and the project turned out to be one of the largest systematic investigations of a burial assemblage in recent times around Yeoju. The archaeological features consisted of 24 stone-chamber tombs and 8

Bong Won Kang is a Professor in the Department of Cultural Resources Studies, Gyeongju University, South Korea. 


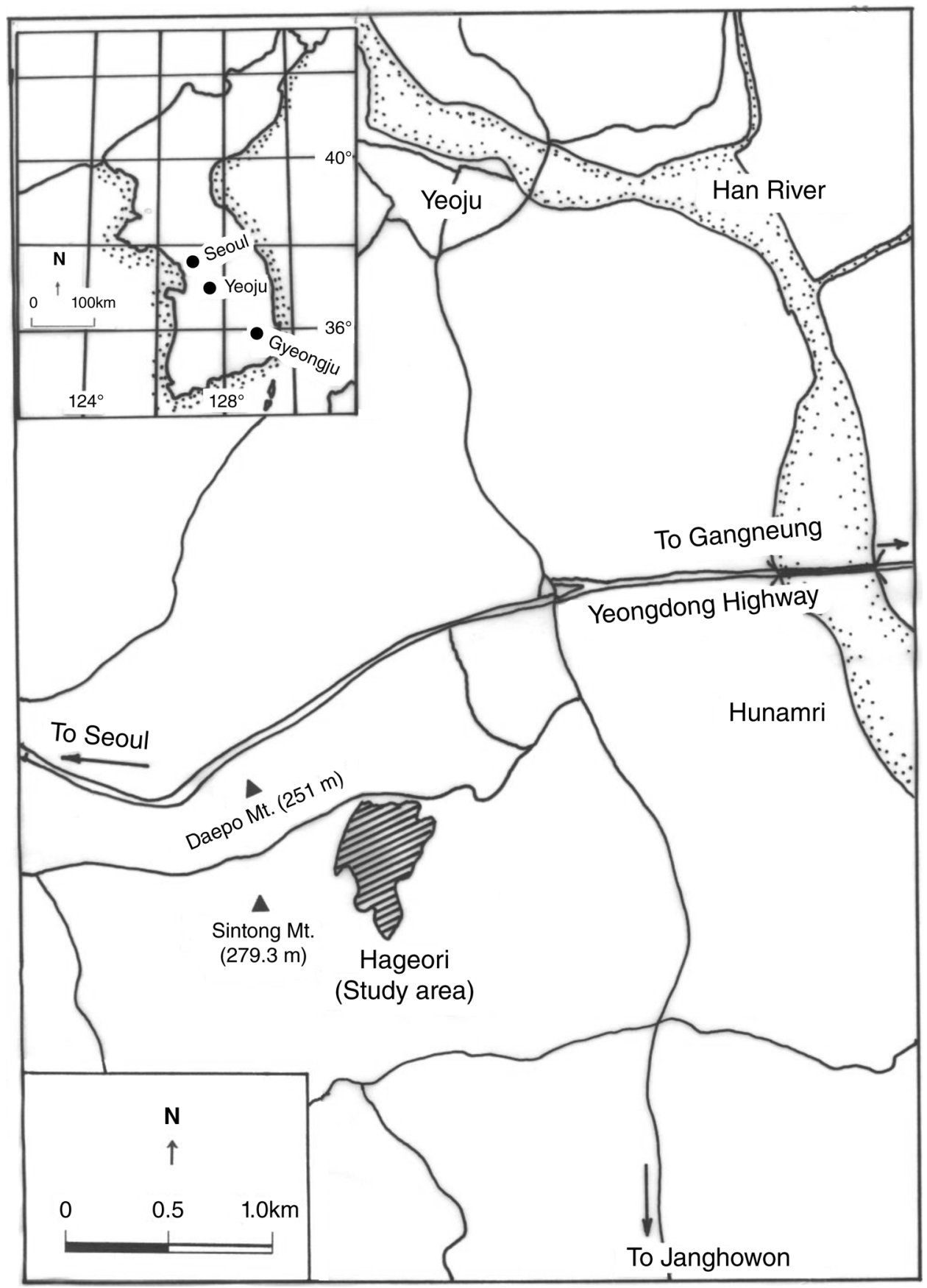

Fig. 1. The location of the Hageori site (study area). 


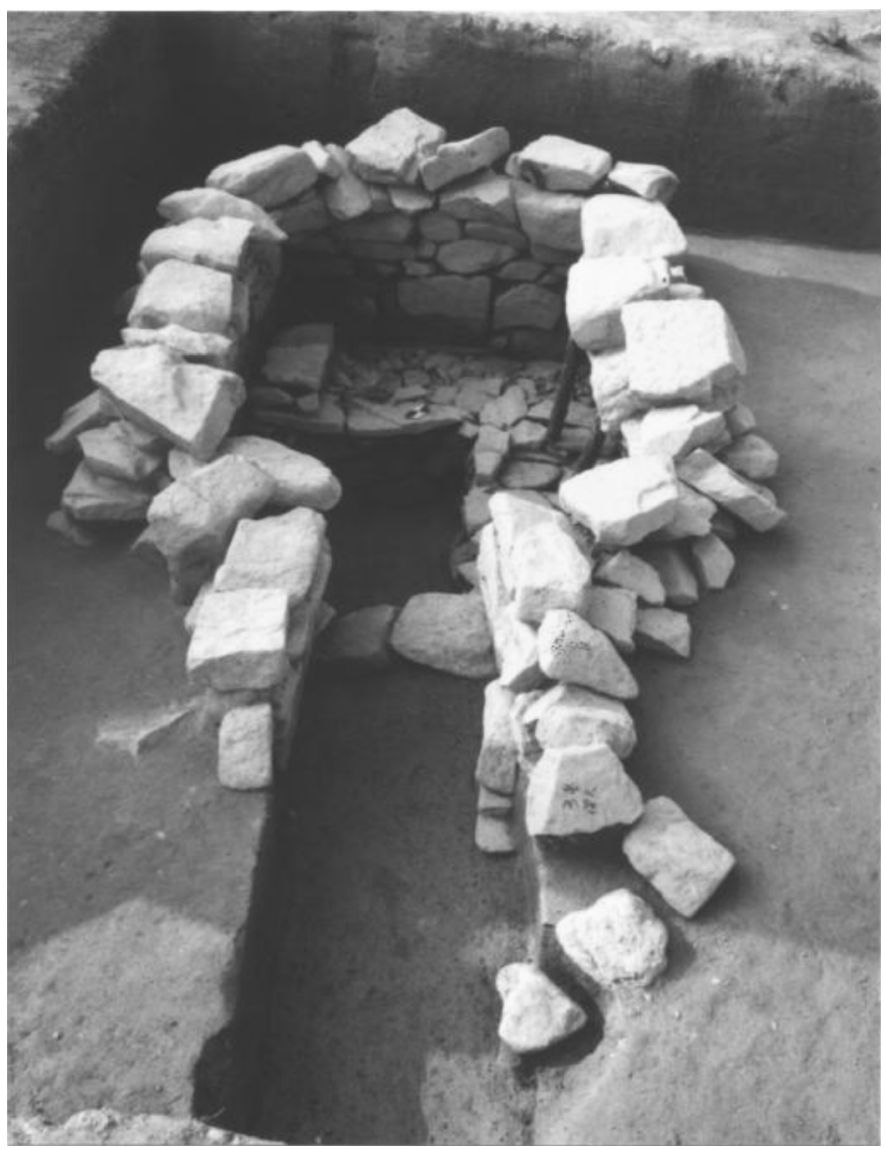

Fig. 2. Passage chamber tomb (Tomb No. 3).

Three Kingdoms period; all the dates used in this paper are A.D., unless noted otherwise), 2 stone-lined pit burials, 15 pit burials (dating to between the tenth and fourteenth centuries: Goryeo Dynasty), and 5 mortars (a mixture of lime and sand) and 2 pit burials (dating to between the fifteenth and early twentieth centuries: Joseon Dynasty).

I conducted mortuary analysis on 24 of the stone-chamber tombs. In addition to the stone-chamber tombs, 8 small stone cists considered to be contemporaneous were also discovered at the site. Those tombs were excluded from the data set because they had been disturbed to such an extent that the burial attributes used in this analysis could not be determined for them.

The objective of this article is to introduce Western archaeologists to ancient Korean mortuary practices. Using archaeological and documentary data, I discuss the chronology and the ethnic group of the tomb builders. I also examine how and why mortuary customs changed over time, as well as the relationship between energy expenditure and vertical social position based on the stylistic variation between burials. 


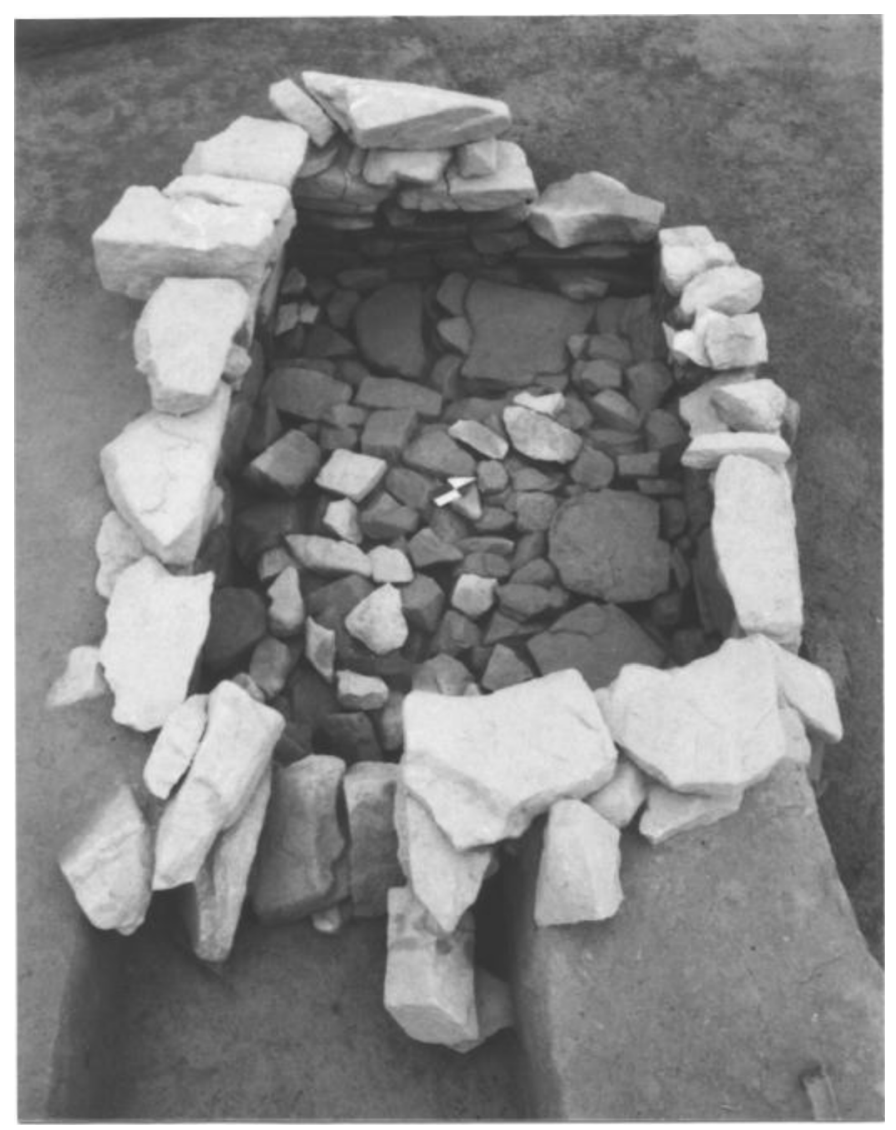

Fig. 3. Entrance chamber tomb (Tomb No. 11).

\section{MORTUARY BEHAVIOR AT HAGEORI}

In terms of the number of burials excavated, the Hageori project was one of the biggest data recovery programs in the immediate area. Although most of the burial structures had been damaged by postdepositional processes, such as looting, erosion, and/or agricultural practices, nevertheless the archaeological data contributed to our understanding of the burial practices of the early Baekje Kingdom in ancient Korea.

A few different types of stone-chamber tombs were identified at the site. Korean archaeologists have adopted various classification criteria, but the minute distinctions are irrelevant here. Since this paper is not concerned with burial typological issues, all stone-chamber tombs are simply divided into two different types: 1) stone-chamber tombs with an elongated passage (Figs. 2, 3), stonechamber tombs with an entrance (Fig. 3) (in this article called passage-chamber tombs-PCTs, hwenghyeol-sik seoksilbun); and 2) entrance-chamber tombsECTs, hwenggu-sik seoksilbun. In Korea, these two are typically classified within the same burial category because the method in which the corpses were interred (horizontally) into the chamber tombs is identical. 


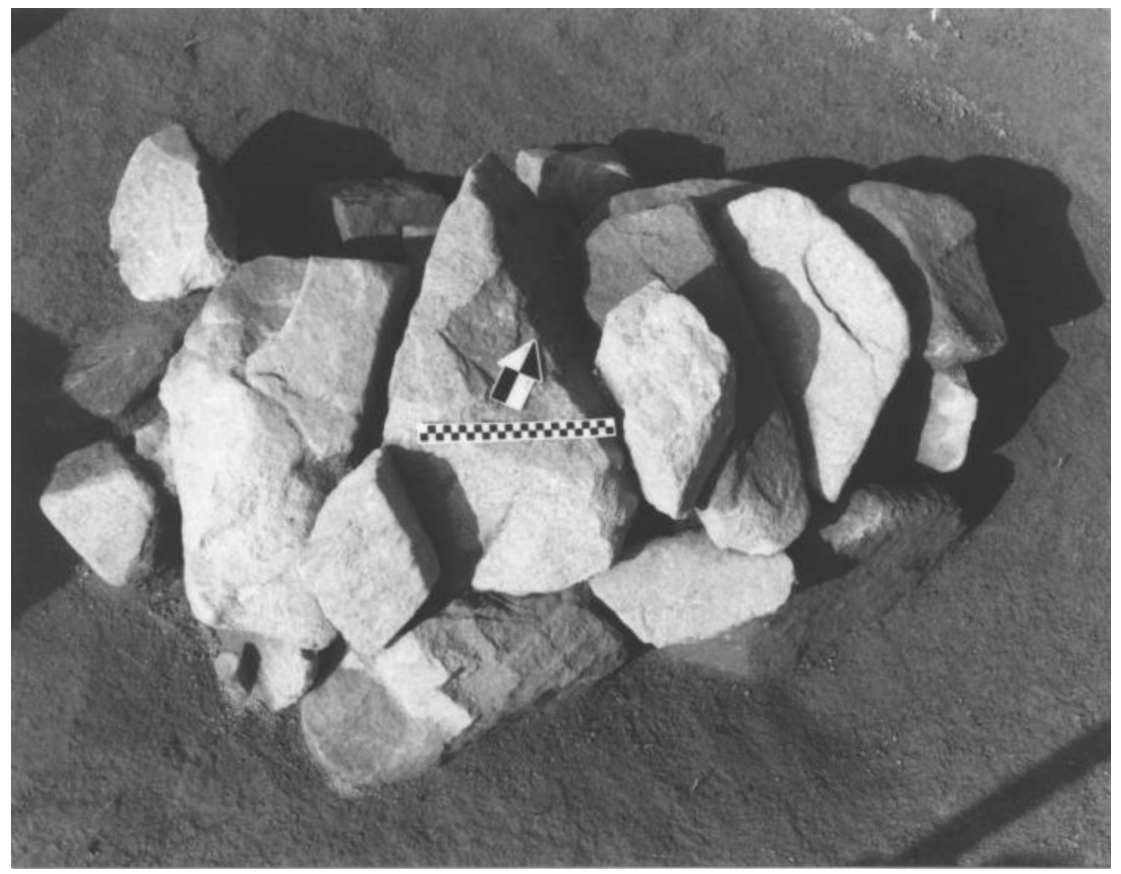

Fig. 4. Stone cist (Tomb No. 8-A, before excavation).

Interestingly, a few very small burials were also discovered in the vicinity of both PCTs and ECTs at the site. These are called stone cists (Figs. 4, 5). Judging from their size, they were apparently built for children under the age of two or three. These features were not analyzed for this paper; rather, they are important because they demonstrate that formal children's burials were present at this cemetery.

There are some small stylistic differences between PCTs and ECTs. To distinguish between the two, the criterion adopted for this article is the presence or absence of an elongated protruding side-passage attached to either a rectangular or squarish tomb chamber. PCTs have rectangular chambers linked to the outside by a short passage (see Fig. 3). In other words, a narrow and short, unpaved passage leads to a subterranean rectangular burial chamber of about $4-6 \mathrm{~m}^{2}$ in which corpses were placed. The mean length of all passages $(n=12)$ is $86 \mathrm{~cm}$, the mean width $63 \mathrm{~cm}$, and the mean height $67 \mathrm{~cm}$. This passage, which was usually installed in the middle, but occasionally either on the right-hand side or the lefthand side of the short axis of the chamber walls, is lower than the ceiling of the chamber and higher than the floor of the chamber, where generally one has to stoop to enter the inside of the chamber tomb. Judging from a few undisturbed examples of stone-chamber tombs at this site, it appears that the passage was never roofed.

On the other hand, ECTs have a small entrance through which people could gain access to the inside of a chamber (see Fig. 3). An entrance was built in a small part of the short axis of the chamber walls. Thus, in the case of ECTs, there is no protruding passage attached to the chamber. The mean entrance is $59 \mathrm{~cm}(n=8)$ 


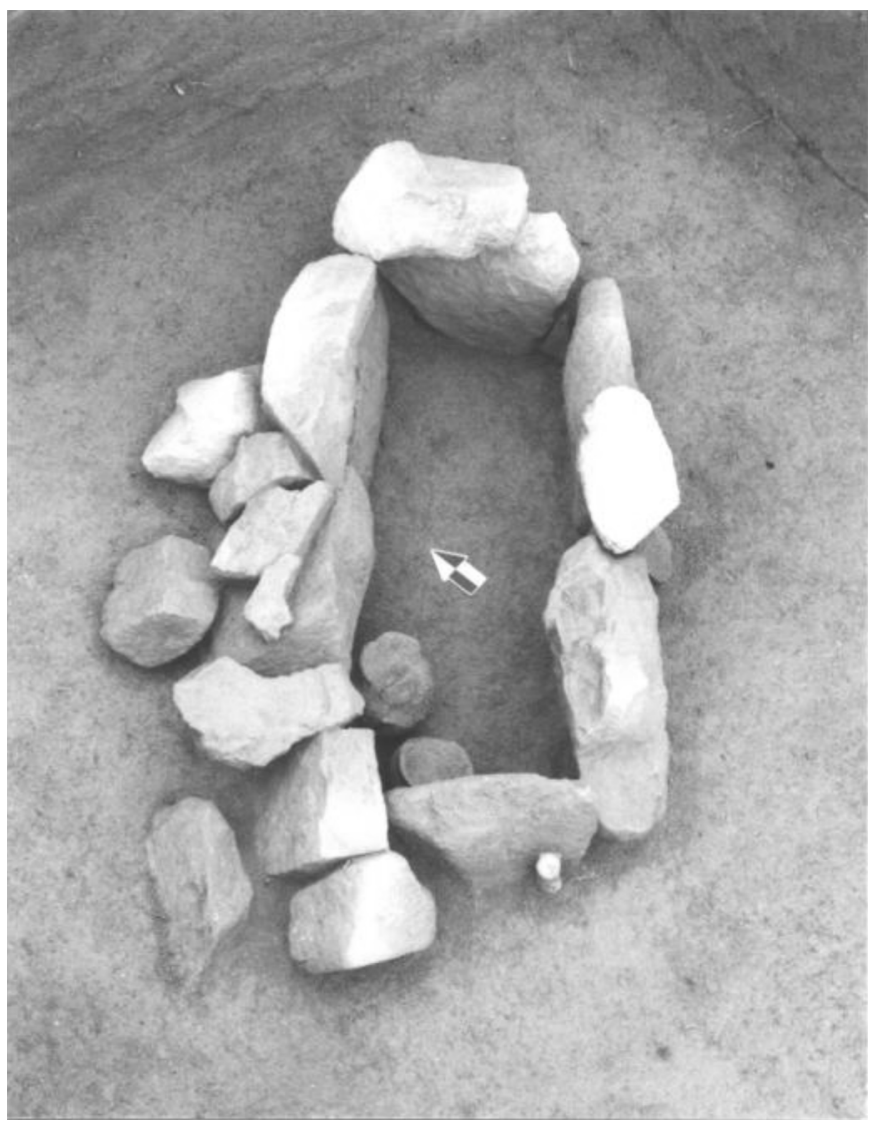

Fig. 5. Stone cist (Tomb No. 8-A, after excavation).

wide, $57 \mathrm{~cm}(n=7)$ high, and was usually installed in the middle of a short axis of chamber walls. Occasionally, however, the entrance is to be found either on the right- or left-hand side of a short wall as in the case of the location of the PCTs' passage.

As was mentioned previously, there are some minute variations in tomb style between PCTs and ECTs. Many Korean archaeologists have regarded such small differences as critical criteria in making a distinction in social status: PCTs were used by the upper class, while ECTs were employed by the lower class (An 1989:70; Yi 1995:305, 417). However, it seems that the stylistic difference between the two burial types is not associated with any social or economic status. Rather, it may have been the result of temporal factors (see below). As far as the relative chronology is concerned, it is generally accepted that PCTs are earlier than ECTs (Choi 1997: 103; Yi 1995 :353, 362, 417).

In terms of the characteristics of stone-chamber burials, both types of stonechamber tombs have a subrectangular, subterranean chamber. Sometimes they even appear to be oval in plan view. Four-sided chamber walls, which support a ceiling, are made of from three to five thick and elongated slabs (Fig. 6). Both the 


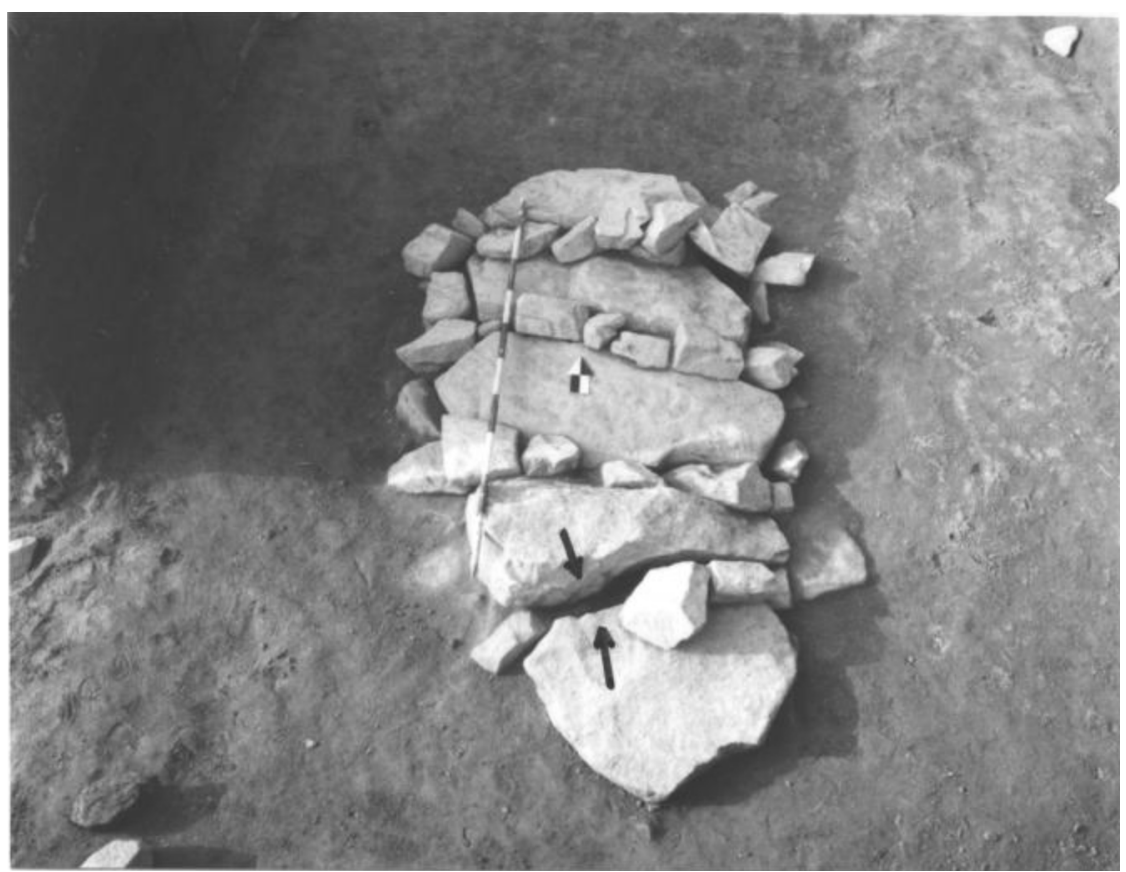

Fig. 6. Capstones of a passage chamber tomb (Tomb No. 15).

passage and the entrance to the chamber were closed by moveable boulders that blocked the outside of the passage.

These are typical examples of multiple burials in Korea. In these burials, inhumation, rather than cremation, appears to have been the norm. It is evident that by adopting the multiple-burial program, villagers preferred to accommodate more individuals, rather than have separate burials. That is, when other members of the family died at different times, they likely removed the boulders that blocked the passage or entrance, reopened the chamber, and placed the corpse or corpses in the chamber through either a passage or entrance. In this time period, it appears to have been common for additional individuals to be buried in the same chamber in succession. So far, the discovery of skeletal remains has not yet been reported around the study area. Thus, we are unable to figure out how people treated the dead body(ies) previously interred in the burial. The recovery of two pottery vessels in front of the passage of Tomb No. 3 leads us to believe that ritual practices may have been conducted there.

The inside of a chamber becomes narrower from floor to roof, and the walls of the long axis usually incline toward the inside. Thus, much of the cross section of the internal structure of stone-chamber tombs is in the form of a trapezoid. This suggests that the builders may have put heavy, elongated rocks on top of stonechambers to cover the entire chamber tomb. Thus, although the elongated capstones are much shorter than the maximum width of stone-chamber tombs, the capstones are well fitted to cover the chamber entirely.

Two or more elevated stone platforms for corpses are constructed with several boulders along the inside walls of the PCT, while the rest of the chamber tomb 


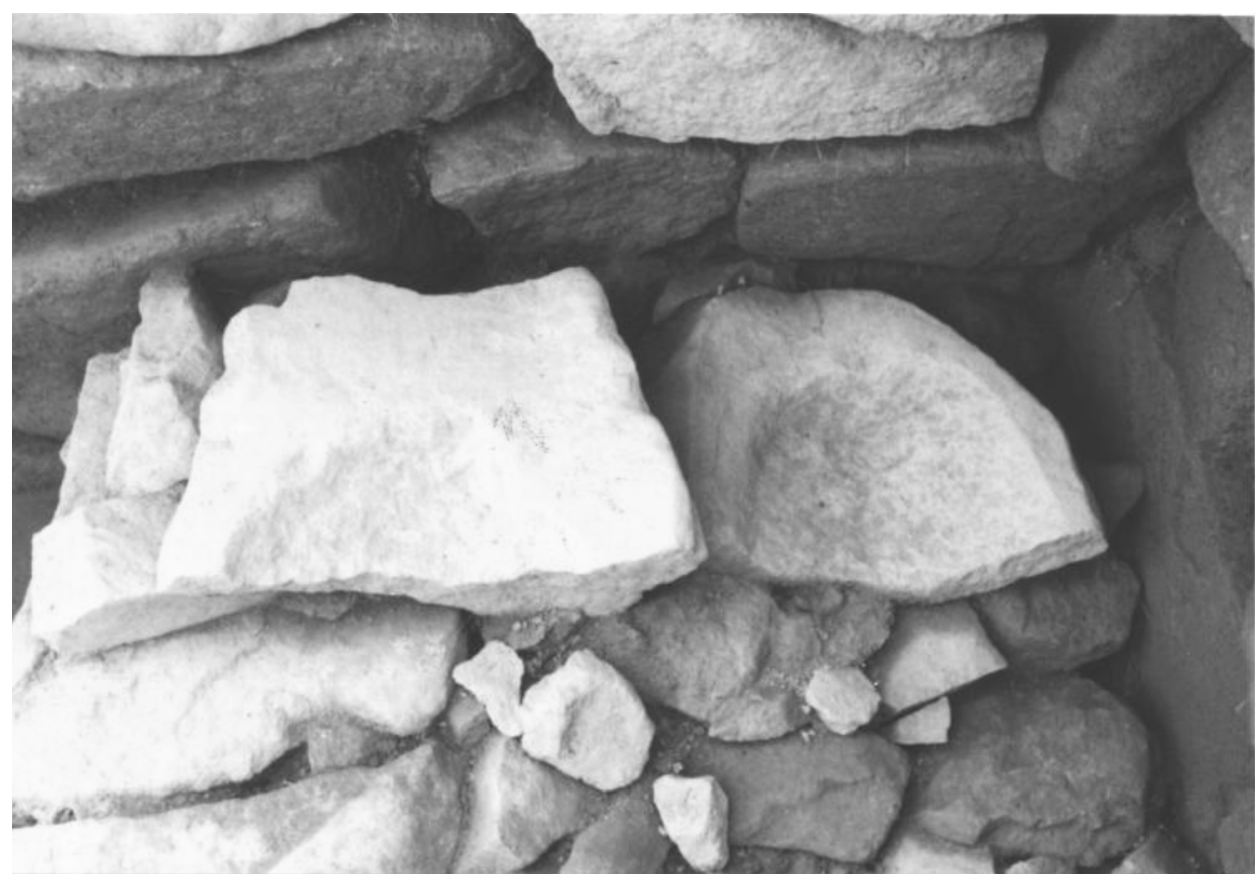

Fig. 7. Stone headrest placed on stone platforms in chambered tombs (Tomb No. 3).

lies on sterile soil (see Fig. 7). The tops of the stone platforms [biers] are paved with modified rocks, suggesting that the tomb builders probably placed the corpse(s) on top of this elevated platform. It is of interest to note that a few headrests were recovered from the chamber tombs (Fig. 8). Although some headrests were moved away from their original locations, others were found at the ends of stone platforms as originally placed. The presence of headrests at the end of stone platforms implies that people did not use any kind of coffin for internment. It can be inferred that the corpses were placed on the elevated stone platforms in an extended position.

Most of the floors of ECTs were paved with modified rocks (see Fig. 3). In these cases, there are no independent stone platforms installed inside of the tombs. A few probable headrests were identified in this kind of chamber tomb as well. This implies that the corpses were placed in an extended position, without a coffin, on floors paved with modified and/or natural rocks.

Although no earthen mounds were found on the top of any stone-chamber tombs, hemispherical earthen mounds probably were built at the time the stonechamber tombs were constructed. As time passed, postdepositional processes such as agricultural practices and/or natural agents probably wore down these mounds.

Skeletal remains were not recovered from inside the stone-chamber tombs. The lack of bone preservation is partly due to postdepositional processes, but acidic soil seems to have played the most critical role in bone decay. It is not uncommon to find extremely poor skeletal preservation in Korean burials. In order 


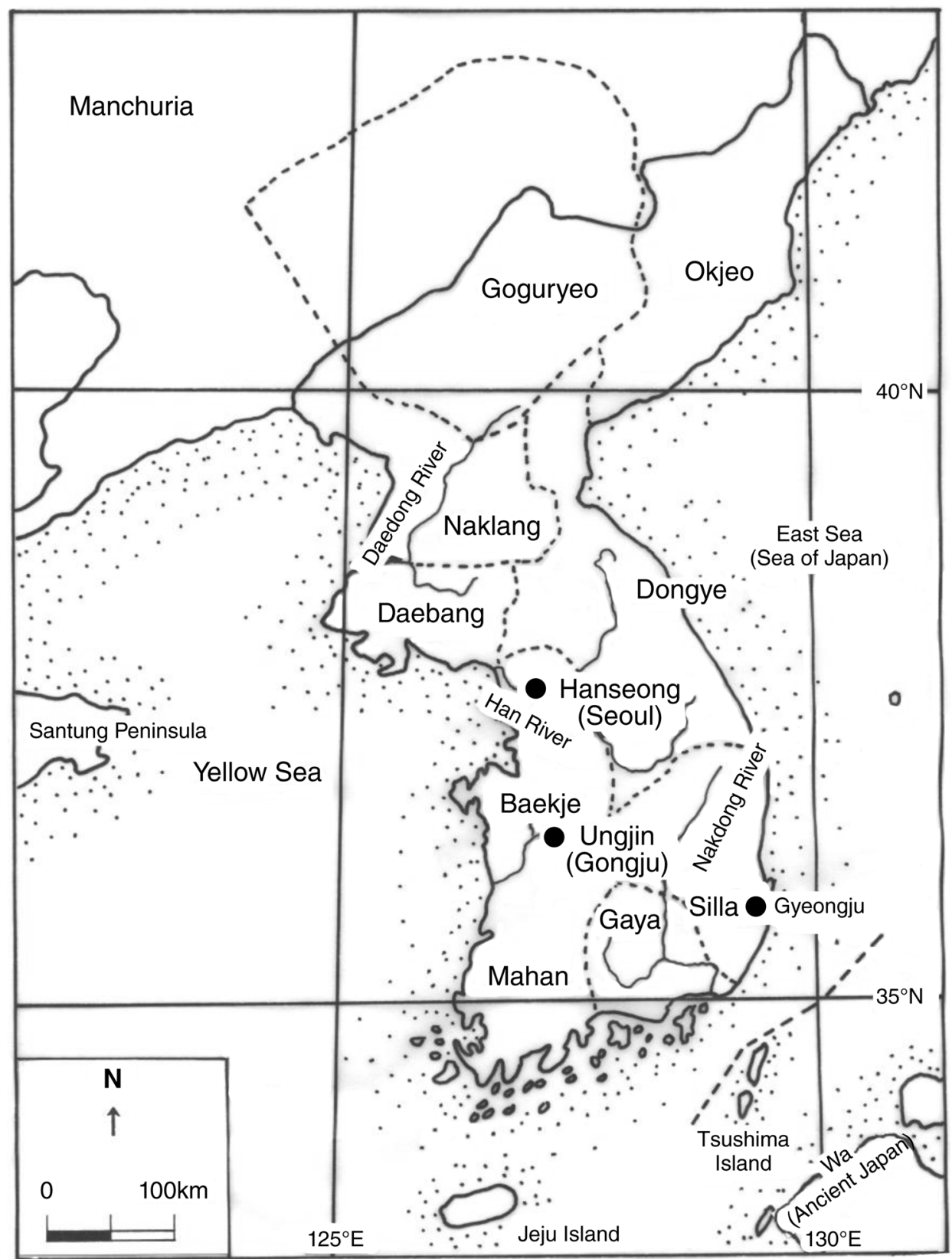

Fig. 8. The map of Korea during the Three Kingdoms period (c. the third to fifth centuries).

to determine the characteristics of the soil at the site, Advantec $\mathrm{pH}$ Test Paper (Whole Range, pH 0-14; Toyo Roshi Kaisha, Ltd., Japan) was used. The soil found around stone platforms and the inside of all stone-chambers was tested. The $\mathrm{pH}$ level at the site turned out to range between 4 and 5 , which is quite acidic. This test was not precisely conducted but provides an approximate $\mathrm{pH}$ level of 
the soil around the Hageori site. Thus, it is evident that the acidic soil played a significant role in the poor skeletal preservation. As a consequence, demographic information, such as the ratio of age and gender, nutrition, and pathology of the interred people, as well as other important bioarchaeological data, is not available.

\section{DETERMINATION OF CHRONOLOGY AND ETHNIC GROUPING}

The determination of accurate chronology is one of the greatest archaeological issues in Korea, and the Hageori site is no exception. In order to determine the chronometric chronology, two samples of charcoal were collected from inside the chamber tombs and sent to a radiocarbon dating laboratory. The results were Beta-118796 $640 \pm 80$ B.P., or A.D. $1345 \pm 60$, and Beta-118797 $360 \pm 60$ B.P., or A.D. $1550 \pm 90$, respectively. These dates are not acceptable in light of the historical and other archaeological evidence found at the site, and in many parts of Korea in general. Thus, there is a high possibility that the charcoal samples were contaminated. Therefore, I used typologies and seriations of burial structures and grave goods recovered from mortuary contexts in an attempt to estimate appropriate relative chronologies for stone-chamber tombs and other types of burial. In addition, I used evidence from the Samguk sagi (History of the Three Kingdoms), the oldest extant Korean history (written in Chinese characters), to confirm the general historical atmosphere in relation to the relative chronology of the burials in the study area. By combining these data, I estimated that the stone-chamber tombs, as well as the stone cists recovered adjacent to the chamber tombs, date to between the fifth and seventh centuries. This time range generally corresponds to the one that many other Korean archaeologists have been adopting.

Determining an accurate chronology is important not only because it is directly related to the identification of the ethnic group of the tomb builders, but because it is integral to understanding a large portion of ancient Korean history. If we are able to create a relatively accurate chronology of the Hageori burials, it becomes quite simple to identify the ethnic group of the builders of the stone-chamber tombs, as we already know the general historical background of ancient Korea. This is because the borders of the Three Kingdoms changed several times, especially between the second half of the fifth and middle of the sixth century, according to historical sources and archaeological evidence. By the same token, if we can determine the ethnic group in the stone-chamber tombs, we can determine approximately when the ancient people of Hageori began to construct stone-chamber tombs.

Since the Japanese Imperial occupation of the Korean peninsula in 1910, a large number of side-entrance stone-chamber tombs (i.e., hwenghyeol-sik seoksilbun or PCTs) have been excavated in Seoul and its vicinity, including Yeoju. Influenced by the viewpoints of Japanese archaeologists, until the early 1970s it had been generally accepted by Korean archaeologists that those stone-chamber tombs were built by the Baekje people. However, Kim (1974), a pioneering Korean archaeologist, argued that the stone-chamber tombs in Yeoju and the adjacent area might have been built not by Baekje but by Silla people after the middle of the sixth century or even in the seventh century. Since then, there has been controversy over the chronology, particularly surrounding the ethnic group of the stone-chamber tomb builders of Yeoju and other areas around Seoul. As time 
progressed, the number of Kim's (1974) followers increased (e.g., Chamsil Area Archaeological Team 1978:18-28; Choi 1992; Kang 1996). According to them, the majority of the stone-chamber tombs in Yeoju were constructed by Silla people after the middle of the sixth century (Choi 1992; Im 1995; Kang 1996; Kim 1974). They based their arguments primarily on historical records. According to the Samguksagi, King Jinheung (540-576) of the Silla Kingdom conducted a wide range of military campaigns for the purpose of territorial expansion, to the north in particular. The king had a strong desire to acquire arable land around the lower reaches of the Han River, including a trade route to Chinese dynasties.

Originally, the entire Han River basin, including present-day Seoul and the study area, were part of the Baekje Kingdom's territory until 475. Goguryeo, by relocating its capital from Toung Kou to Pyeongyang (the same as present-day Pyeongyang) in 427, showed a strong desire to expand its territory to the southern Korean peninsula. Threatened by Goguryeo's political ambition, the Baekje and Silla Kingdoms established a military alliance between King Biryu (427-455) and King Nulji (417-458) in 433. Nevertheless, Goguryeo invaded the capital of Baekje and killed King Gaero in 475. Thus, Baekje was forced to relocate her capital from Hanseong (present-day Seoul) south to Ungjin (present-day Gongju). From that time on, Goguryeo occupied the Han River basin and the study area of the Baekje territory for nearly 80 years until the allied forces of Baekje and Silla drove Goguryeo soldiers away. The allied forces of the Silla and Baekje Kingdoms drove the Goguryeo Kingdom's military forces out of the Han River basin between 551 and 553. But soon after this military campaign, Silla drove the Baekje's military forces out of the region and took sole control of the entire Han River basin, including the study area. Consequently, the strategic military alliance between Silla and Baekje against the political influence of Goguryeo was broken.

With this historical background, there is an important thing to which we must pay close attention. That is, it is of interest to know if the mortuary customs in the Yeoju area were influenced by the political turmoil that took place in the middle of the sixth century. Based on historical facts and some archaeological observations, a few Korean, Japanese, and Western archaeologists have argued that the stone-chamber tombs excavated in the Yeoju area were constructed by the Silla people, not by the Baekje people (Barnes 2001:223; Kim 1974, 1982; Nishitani 1981:119). In other words, they argue that the presence of the stonechamber tombs was the direct outcome of the territorial expansion of the northern frontier carried out by the Silla Kingdom in the middle of the sixth century. Consequently, they have asserted that the stone-chamber tombs in Yeoju should be dated to between the second half of the sixth century and the seventh century.

I believe that the stone-chamber tombs and stone cists discovered at the Hageori site and in Yeoju in general were constructed by the Baekje people sometime between the fifth and the seventh centuries. Although the Yeoju area became part of the Silla territory from the middle of the sixth century onward, the area originally belonged to the Baekje Kingdom until 475. Therefore, there is a strong possibility that the stone-chamber tombs can be dated even to the early fifth century. If there was a shift from Baekje to Silla type in the mortuary program in the Han River basin, it would have been gradual and it may have taken 
place at least from the second half of the seventh century, when Silla achieved the unification by destroying Baekje (in 660) and Goguryeo (in 668), respectively.

Whenever mortuary practices are examined, there is one anthropological or archaeological principle that should be taken into consideration: mortuary practices are extremely conservative and exhibit "long-term stability" (Binford 1971:15). Thus, even if Yeoju became part of the territory of the Silla Kingdom in the middle of the sixth century, it can be posited that the mortuary customs in the area might not have abruptly changed. There are many reasons that the arguments by Kim (1974) and his followers (Chamsil Area Archaeological Team 1978:18-28; Choi 1992; Kang 1996) are not convincing. First, it is a historical fact that this area was the territory of the Baekje Kingdom until 475 (Fig. 9).

The important thing here is that a great number of Baekje people must have lived in their territory, including Yeoju, for nearly 500 years (between c. the Christian era and 475) and left a considerable number of burials. Furthermore, it is hard to imagine that the majority of Baekje people who lived in the capital and its adjacent areas retreated to Ungjin with the royal families and the upper classes of the kingdom. Even if Goguryeo occupied the Yeoju area, it is difficult to accept that the Yeoju people adopted Goguryeo burial customs instantaneously. It is curious that Korean archaeologists who consider the Silla people to be the ethnic group responsible for the stone-chamber tomb construction have not discussed in detail the role of either the Goguryeo people or the effect of their mortuary practices between 475 and 553 in Yeoju. If those Korean archaeologists are correct, we should be able to find some burials constructed by the Goguryeo people in Yeoju as well. If the stone-chamber tombs excavated at the site and other areas in Yeoju are considered to be those of either Goguryeo or Silla, there would not be any Baekje burials at all. Thus, it is not surprising to see that almost no Goguryeo burials have been identified around Hanseong (present-day Seoul), the old capital of the Baekje Kingdom and its vicinity.

Second, by the same token, it is a historical fact that the Silla Kingdom expanded their territory to the north and occupied the entire Han River basin, including the area under study. However, it is hard to accept that the local indigenous Baekje people gave up their own traditional mortuary practices and adopted new ones right away. This is because, as mentioned above, mortuary behavior is regarded as one of the most conservative aspects of human culture. If the Hageori stone-chamber tombs were indeed constructed by Silla people, the tombs must have had been built by the local administrators who were officially sent by Silla to govern the area. But this scenario does not seem plausible. As can be seen on the map (Fig. 9), similar types of contemporary burials (i.e., both types of PCTs and ECTs) have been identified in many different places around Yeoju, suggesting that the stone-chamber tombs were not reserved and built for the local administrators sent to this area by the centralized Silla government. Rather, many of the stone-chamber tombs were constructed according to the traditional mortuary customs of Baekje people who had not been much influenced by the Three Kingdom's political turmoil.

Third, as archaeological evidence, Kim (1974) and his followers (e.g., Choi 1992; Kang 1996) put forward close stylistic similarities between the stonechamber tombs recovered in Yeoju and those in Gyeongju, the ancient capital of 


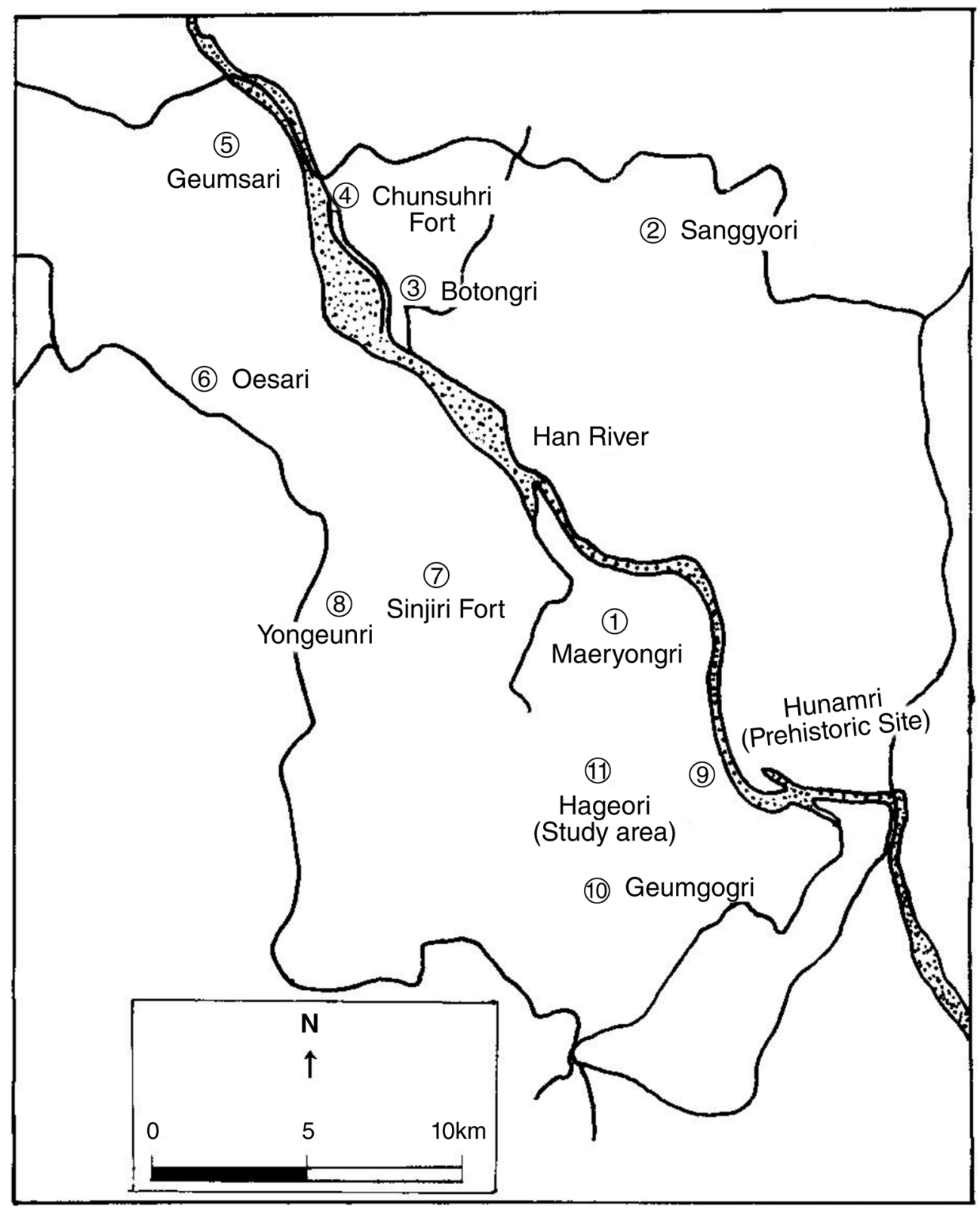

Fig. 9. Yeoju County, showing locations of stone-chamber tombs and other archaeological sites. (Modified from Y-H Choi et al. 1988: 19, Fig. 7)

the Silla Kingdom. They relate the similar stylistic traits to the Silla Kingdom's territorial expansion, which was accomplished by King Jinheung in 553. It is true that there are some stylistic similarities in burial practices that have been identified in the two different regions, but that does not necessarily mean that Silla people built the stone-chamber tombs uncovered in Yeoju. In fact, it has been interpreted the other way around. Many Korean archaeologists have generally 


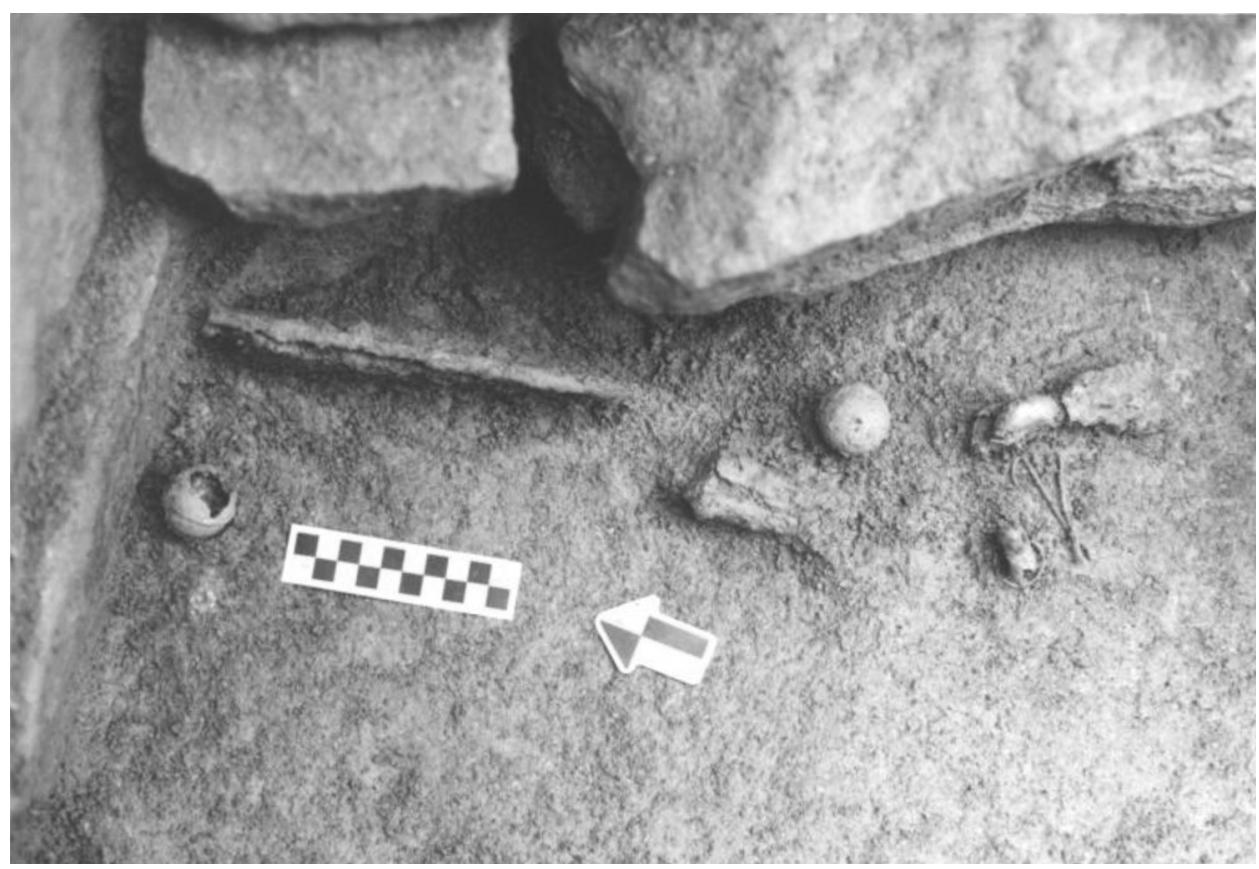

Fig. 10. Metal artifacts from No. 2 stone-chamber tomb entrance.

accepted that the stone-chamber tombs of the Baekje were influenced by the Goguryeo first, and then the burial practices of the Silla were influenced by the Baekje over time (Choi 1992:483; K. Kim 1976a:49-50, 1976b:59-60; W. Kim $1982: 108$ ). That is, the horizontal-entrance stone-chamber tomb (hwenghyeol-sik seoksilbun) first appeared in Goguryeo, next in Baekje, and then finally in Silla. It should be kept in mind that the major mortuary program practiced in the heartland of Silla between the middle of the fourth and the middle of the sixth centuries was not the stone-chamber tomb but the stone-surrounded wooden chamber vertical-entrance tomb (jeokseok mokkwakbun; Pearson et al. 1989:1). They are two completely different mortuary programs in terms of burial style. As time progressed, and especially with the official adoption of Buddhism in the first half of the sixth century by the royal families of the Silla Kingdom (between 527 and 535), the jeokseok mokkwakbun became much smaller in scale and less sumptuous, and was eventually replaced by the stone-chamber tomb. Accordingly, the stonechamber tombs discovered in the Yeoju area should be older than the horizontalentrance stone-chamber tombs discovered in the Gyeongju area if the stonechamber tombs discovered in the area were indeed built by the Silla people.

Yi $(1995: 252)$ has proposed that the early type of the stone-chamber tomb can be placed in the second half of the fourth century based on archaeological investigations in both the Hanseong (18 B.C.-A.D. 475) and Ungjin (A.D. 475-538) areas of the Baekje region. This chronology is rather convincing because it is based on a great deal of relative dating data and a set of comparatively precise chronometric datum of inscribed tablets discovered in the brick tomb of King Mu-nyeong, built around 523. Therefore, taking into consideration all the mortuary analyses that 
have been conducted on a great number of burials excavated in the entire Baekje territory, the stone-chamber tombs discovered in Yeoju can be dated to the middle of the fifth century (Kang 1983:85-88; Park 1995:92). It is also widely accepted by Korean archaeologists that the original type of PCT was constructed earlier than the ECT in the Baekje region (Cho 1994:37; Choi 1997:103; Hong 1992; Yi 1995:417-424). Overall, however, both PCTs and ECTs coexisted for most of the later part of Baekje history. An important element that should be noted here, then, is that PCTs are earlier than ECTs, and I will return to this point below.

Korean archaeologists have suggested that diffusion and migration might have played an important role in the spread of the Goguryeo Kingdom's horizontalentrance-chamber tomb to the Baekje region (K. Kim 1976a:49-50; W. Kim 1986:224-227). Others have argued that the Baekje's horizontal-entrance stonechamber tomb was influenced by the Lolang's brick tomb style (Yi 1992:109113). One consideration that should be pointed out here is that Kim (1986:176184, 1987:691-707), a leading scholar of his time, who believed that the Silla people were the ethnic group that constructed the stone-chamber tombs in Yeoju, changed his viewpoint later. Among other things, he reversed his view on the chronology of the stone-chamber tombs: "It is wrong to regard the chronology of Yeoju as the seventh century; and it should be earlier [older] than the sixth century" (Kim 1987:707). What he meant by this statement is that the stonechamber tombs in Yeoju were constructed prior to the sixth century. Consequently, because the Silla people could not have constructed the tomb chambers, it is clear that these tombs were built by the Baekje people. Although he did not say why he changed his mind on the chronology issue, he might have taken into consideration the results of pottery analysis conducted by some Japanese archaeologists. He said,

A pottery cup on a short-leg mount (dankakgobae), excavated from Tomb Number 3 in Garak-dong (in Seoul) appeared around 500 A.D, in Japan. So, my chronological viewpoint through which I have regarded the chronology not as old as 500 should be corrected. It should be thought that the Tomb Number 3 in Garak-dong is the tomb of Baekje's (Kim 1987:691).

This is a critical statement because many Korean archaeologists have considered the dankakgobae to be a representative and diagnostic artifact of the Kingdom of Silla located in the southeastern part of Korean peninsula. Therefore, it is difficult to accept their arguments concerning the chronology and the ethnic group of the tomb builders in light of cross-cultural mortuary behaviors in general. In short, the stone-chamber tombs classified as belonging to an early time period at the Hageori site should be dated to at least between the fifth and the early sixth centuries.

\section{ANALYSIS OF THE HAGEORI MORTUARY DATA}

In this section, general mortuary data such as burial orientation, mortuary goods, and energy expenditure will be examined. As was mentioned above, none of the stone-chamber tombs yielded skeletal remains. Consequently, it is not possible to directly determine the orientation of the entire burial features. Fortunately, however, the burial orientation could be roughly determined by using the location of 
Table i. The Orientation of the Hageori Stone-Chamber Tombs

\begin{tabular}{|c|c|c|c|c|c|c|c|c|c|c|}
\hline \multirow{2}{*}{$\begin{array}{l}\text { TOMB } \\
\text { TYPE }\end{array}$} & \multicolumn{5}{|c|}{ NORTHERLY ORIENTATION } & \multicolumn{4}{|c|}{ EASTERLY ORIENTATION } & \multirow{2}{*}{$\frac{\text { OTHERS }}{\text { WWN }}$} \\
\hline & $\mathrm{N}$ & NNE & $\mathrm{NE}$ & NNW & $\mathrm{E}$ & EEN & EES & ES & W & \\
\hline PCT & 3 & 0 & 1 & 0 & 1 & 1 & 0 & 2 & 2 & 2 \\
\hline $\mathrm{ECT}$ & 1 & 2 & 1 & 2 & 2 & 2 & 2 & 0 & 0 & 0 \\
\hline Total & 4 & 2 & 2 & 2 & 3 & 3 & 2 & 2 & 2 & 2 \\
\hline$(\%)$ & 16.7 & 8.3 & 8.3 & 8.3 & 12.5 & 12.5 & 8.3 & 8.3 & 8.3 & 8.3 \\
\hline
\end{tabular}

Total for north $=41.6 \%$; east $=41.6 \%$; others $=16.6 \%$.

Abbreviations: PCT-Passage-Chamber Tomb; ECT-Entrance-Chamber Tomb; N-North; NNE-North-northeast; NE-Northeast; NNW-North-northwest; E-East; EEN-Eastnortheast; ES-Southeast; W-West; WWN-West-northwest.

the long axis of stone platforms in relation to the position of passages and/or the entrance to the chamber. For example, when the entrance or passage is located at the southern end of a chamber tomb, and the long axis of a stone platform is oriented north-south, the burial orientation is considered to be north; in particular, the presence of the headrest is a good indicator of burial orientation. The discovery of a few headrests at the end of the stone platforms allowed us to determine where the head of a corpse was located. Thus, the orientation of the majority of stone-chamber tombs at the site was determined based upon the combination of the locations of passages, entrances, and headrests (Table 1). Table 1 shows that the Hageori people preferred to have bodies buried with their heads to either the east (41.6\%) or the north (41.6\%). An inspection of Table 1 clearly demonstrates that the burial orientation is not random at the site.

It is widely accepted by Korean archaeologists and historians that the preference for easterly orientations in Korean societies might have been related to sun worship, which existed since prehistoric times. Four burials oriented to the west may suggest the possible influence of the adoption of Buddhism by the Baekje Kingdom at the end of the fourth century. Since some Buddhists believe that the Pure Land was located in the Western Paradise, the Baekje people who were presumably influenced by Buddhism may have had a tendency to bury a corpse with its head to the west. Yet the number of burials oriented to the west ( $n=4,16.6 \%)$ at the site is relatively small. The sample size is too small to argue that Buddhism played a key role in determining the burial orientation at Hageori village.

In general, the preference of Korean burial orientation changed over time from the east to the north. This shift, which is believed to have been influenced by Feng Shui geomancy, an ancient philosophy of nature, is believed to have taken place sometime between the fifth and sixth century in Korea (Kim 1974:43). This tendency gradually became the norm for Korean burial practices approximately from the end of the seventh century. In fact, this burial orientation continues to be practiced by many Koreans today. Thus, it is not surprising to see that the majority of the Goryeo Dynasty's (918-1392) burials interred after the middle of the tenth century at the Hageori site are oriented toward the north (16 out of $19,84 \%)$.

Most, if not all, of the stone-chamber tombs at the site were severely damaged by looting and agricultural practices. Thus, an assumption can be made that the 


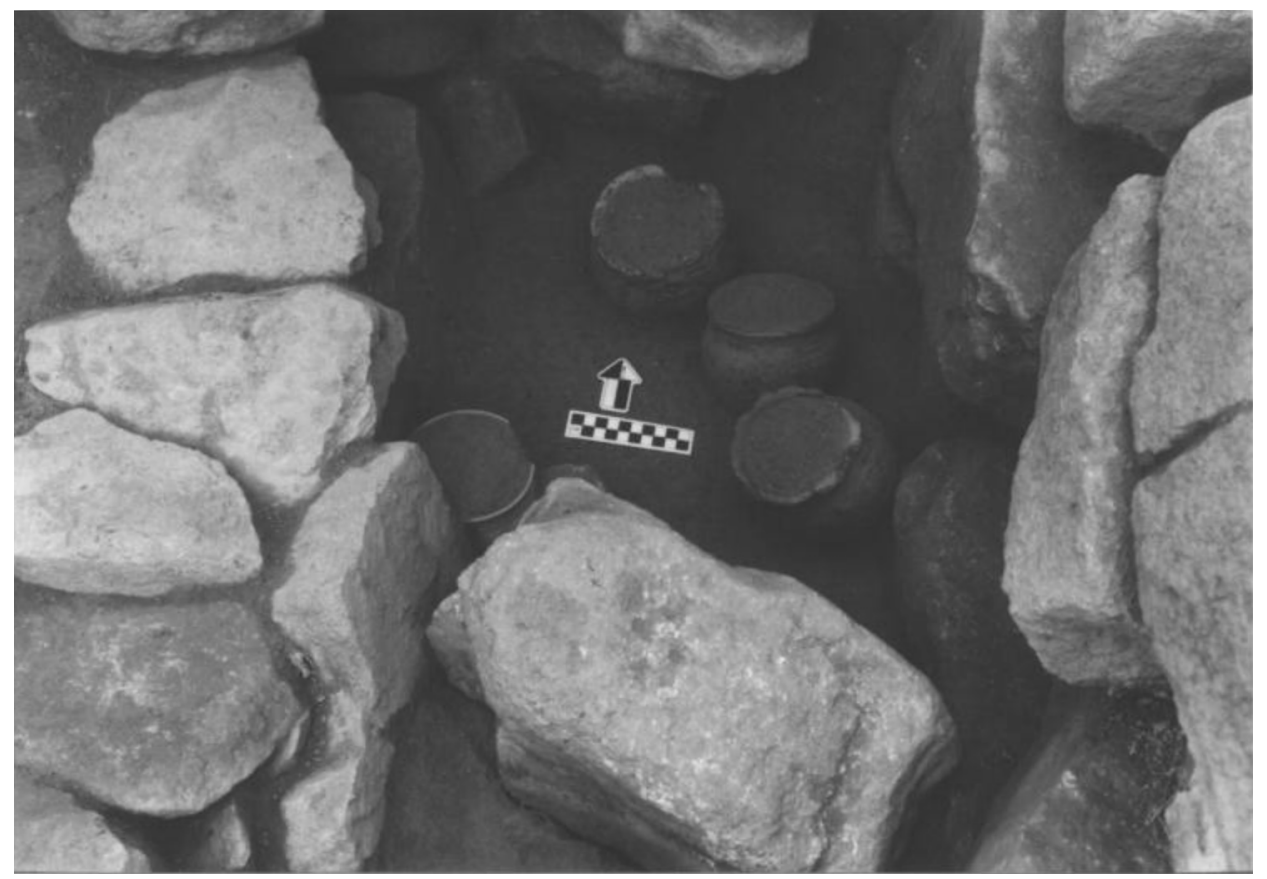

Fig. 11. Ceramic vessels from No. 2 stone-chamber tomb entrance.

majority of grave goods were either looted by pothunters or destroyed by local farmers. Yet, when a few intact stone-chamber tombs were excavated, they did not yield many grave goods. The majority of grave goods recovered in the stonechamber tombs consisted of utilitarian items, particularly ceramic vessels. A few burials, which yielded some mortuary offerings, will be briefly reviewed with some archaeological explanations. Chamber Tomb No. 2 yielded a pair of giltbronze earrings, two bronze bells, one iron bell, one iron chisel (Fig. 11), and four pots (Fig. 12). The mortuary offerings, in particular three metal bells, seem to be paraphernalia used by a shaman. Furthermore, one might consider the owner of the burial to be the religious leader of the village. No. 26 yielded a bronze earring, a gilt bronze ring, and five pots. They are the richest tombs at the site in terms of grave goods. Chamber Tomb Nos. 4 and 10 yielded three vessels and two vessels with one small broken iron knife, respectively. All other chamber tombs yielded only utilitarian ceramic vessels, but the number of pottery vessels in tombs varies slightly.

Chamber Tomb Nos. 5 and 16 were slightly damaged by pothunters. The capstones of the tombs were moved slightly to one side, and it was obvious that pothunters searched for grave goods with a long spit made of steel. A few vessels were broken by the looters' pot-hunting activities, but luckily they remained in situ. In the case of No. 16, although a capstone was slightly moved, the tomb was mostly intact. However, not many artifacts were recovered from these two tombs. This may indicate that the tombs did not originally contain many grave goods. It is widely accepted by Korean archaeologists that the Baekje people buried their dead without many grave offerings. Overall, compared to the great 


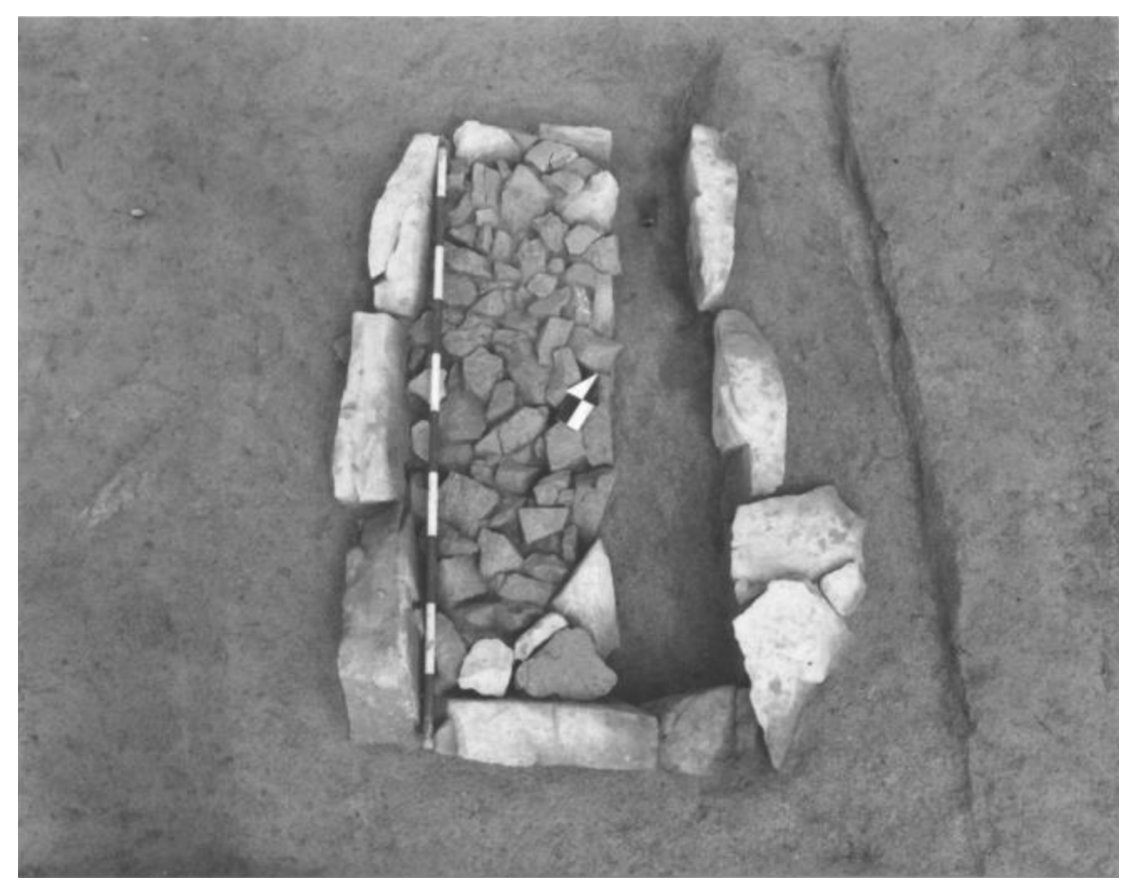

Fig. 12. Entrance stone-chamber tomb with a stone platform (Tomb No. 25). It shows a reduction in the amount of energy expended compared to Plates 1 and 2 based on relative depth and volume.

deal of physical labor expended on stone-chamber tomb construction, the number and prestige of mortuary offerings is insignificant. It is understood that multiple burial was the norm in Hageori from the fifth century onward. There are similarities between Baekje and Silla in terms of the tomb style of the horizontalentrance stone-chamber tomb with multiple burials since the Silla people adopted the basic stone-chamber tomb structures from Baekje. Yet, there are notable differences in tomb structures in terms of temporal and geographical perspectives. However, more detailed analysis of this phenomenon is beyond the scope of this article.

On a global scale, archaeologists have observed that as time progresses and societies become settled, people become reluctant to waste energy on erecting massive burials and offering excessive grave goods (Ucko 1969:266). This burial practice is well confirmed at the Hageori site. Tomb No. 25 shows a dramatic decrease in energy expenditure on tomb construction (Fig. 13). The overall dimension of the burials becomes small. This new tendency of mortuary behavior can be found in many Oriental societies.

In order to examine how energy expenditure in burial construction changed through time, the depth and the volume, respectively, of 12 PCTs and 12 ECTs were analyzed. The depth and volume of a tomb are important variables, because they are directly related to the amount of energy expended to build such features (Table 2).

The mean depth of PCTs is $1.23 \mathrm{~m}$, while that of ECTs is $0.896 \mathrm{~m}$. Thus, there is a significant difference in terms of burial depth between the two types of 


\section{口P.C.T QE.C.T}

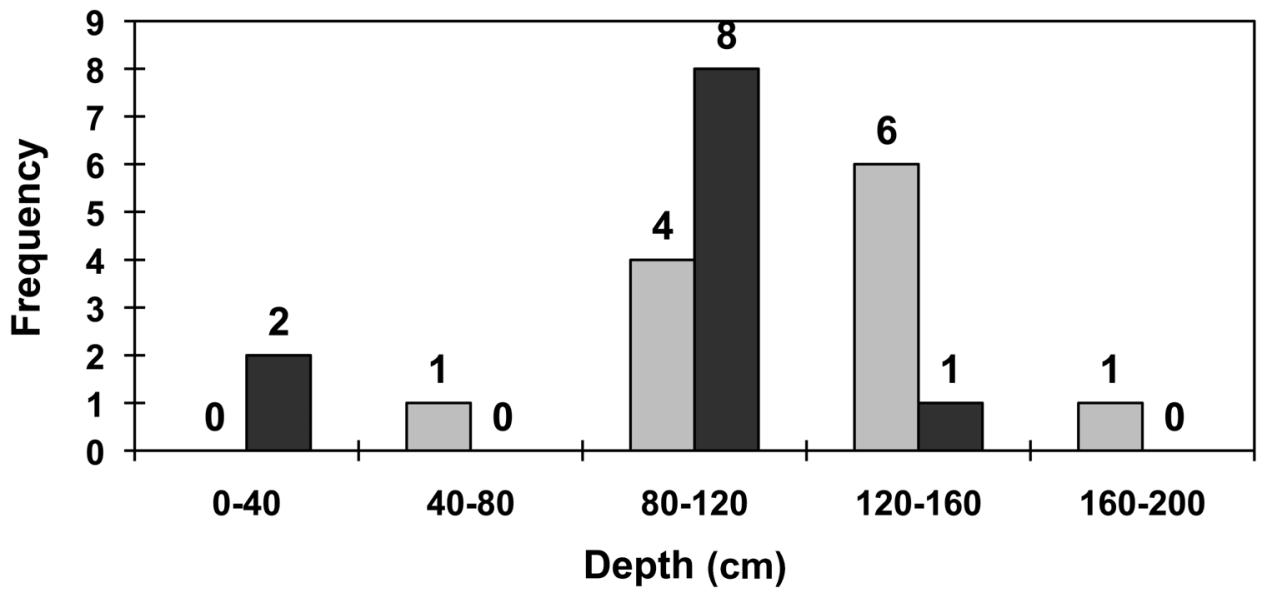

Fig. 13. Frequency of the depth of chamber tombs from the Hageori site.

Table 2. Dimensions of the Depth and Volume of PCTs and ECTs

\begin{tabular}{|c|c|c|c|c|c|c|c|c|}
\hline & \multicolumn{4}{|c|}{$\operatorname{PCT}(n=\mathrm{I} 2)$} & \multicolumn{4}{|c|}{$\operatorname{ECT}(n=\mathrm{I} 2)$} \\
\hline & MEAN & ST. DEV. & MIN. & MAX. & MEAN & ST. DEV. & MIN. & MAX. \\
\hline Depth (m) & 1.23 & 0.22 & 0.5 & 1.5 & 0.896 & 0.196 & 0.32 & 1.29 \\
\hline Volume $\left(\mathrm{m}^{3}\right)$ & 5.01 & 1.11 & 2.01 & 7.41 & 3.41 & 1.60 & 1.02 & 6.57 \\
\hline
\end{tabular}

chamber tomb (Fig. 14). Furthermore, as can be seen in Figure 4, the percentage of relatively deep PCTs $(58.3 \%, 7$ out of 12$)$ is much higher than that of ECTs $(8.3 \%, 1$ out of 12$)$. Since PCTs were probably built relatively earlier than ECTs (but also concurrently), the chamber tombs at the site became increasingly shallow. This mortuary behavior is directly related to the volume of both types of chamber tombs as well (Figure 14). That is, the mean volume of PCTs was $5.01 \mathrm{~m}^{3}$, while that of ECTs was $3.41 \mathrm{~m}^{3}$. As can be seen in the figure, the percentage of large PCTs $(58.3 \%, 7$ out of 12$)$ is higher than that of ECTs $(33.3 \%$, 4 out of 12). A combination of data on both depth and volume of chamber tombs strongly suggests that the energy expenditure on the construction of ECTs was noticeably less than for PCTs (see Table 2). In addition, the standard deviation of the volume of ECTs is slightly greater than that of PCTs. The difference between the two types of burials in terms of both standard deviation and mean suggests that the overall burial scale of ECTs was smaller than that of PCTs.

At the site level, the labor and administration that was needed to construct these relatively big tombs compared to those of a later time period may suggest the sociopolitical power of leaders in the area. However, the energy expenditure and labor organization do not seem to automatically indicate the presence of 


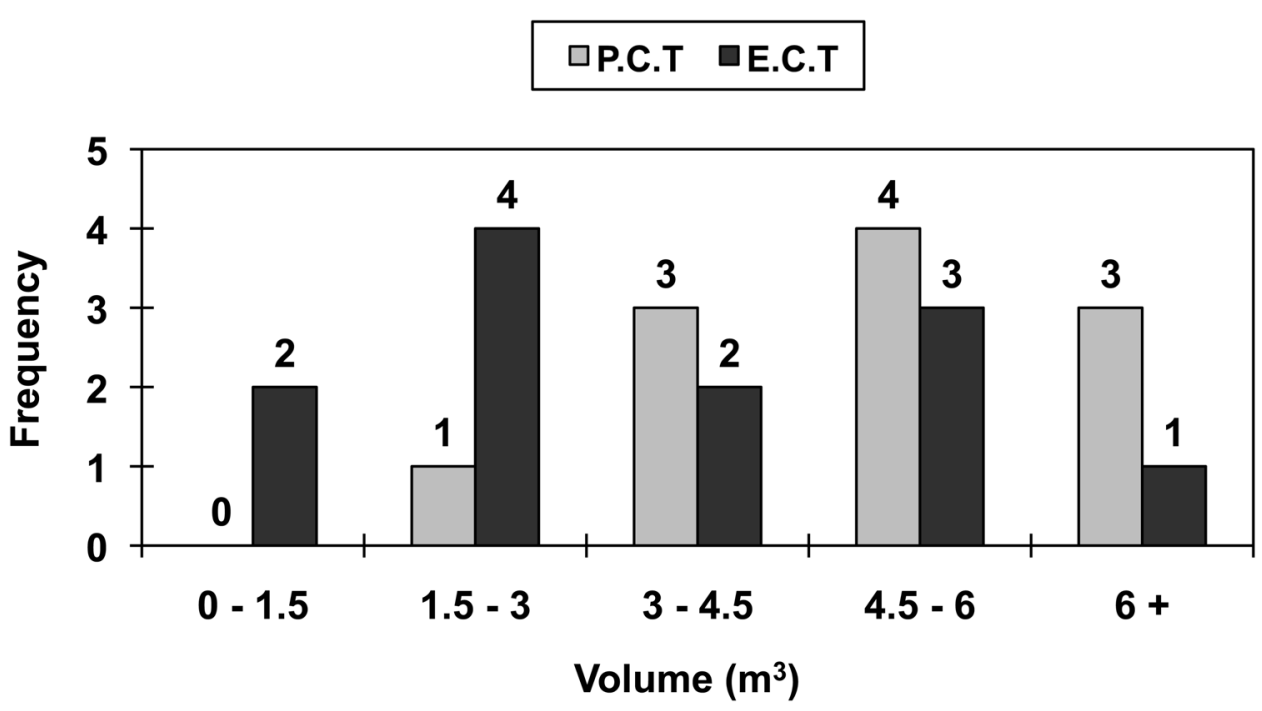

Fig. 14. Frequency of the volume of chamber tombs from the Hageori site.

a strong social hierarchy. This is because this contemporary type of burial has been identified in many different places in the vicinity of the Hageori site and Yeoju (Fig. 10), indicating that similar burial structures were constructed contemporaneously in many different parts of the Baekje territory. It has been shown that there are some stone-chamber tombs on which a great deal of energy was expended. However, overall the quality and quantity of mortuary offerings deposited in the burials does not show any significant discrepancy between bigger tombs and smaller ones and the differences are negligible. Therefore, it seems highly likely that most ordinary people may have adopted more or less the same tomb style in the village and its vicinity as well.

\section{INFERENCES OF SOCIAL STATUS}

Mortuary treatment has been regarded as a critical element from which to infer the social status of the dead. Energy expenditure, among other things, has been considered one of the most important variables whenever mortuary programs are examined (Binford 1971:21; Brown 1981:29, 32; Carr 1995:178-180; Chapman 1995:45-46; Härke 2000:373-374; Saxe 1970:111; Tainter 1975:2, 1978:125-128). In the case of the ancient Korean burial program, abundant examples show a strong positive correlation between the amount of energy expenditure on burials and the social status of the buried. Considering the theoretical discussions concerning energy, I make some brief inferences about the social status of those buried at the site.

It has been argued that the presence of a high-status individual does not mean that the entire village was stratified. Even in predominantly egalitarian societies, individuals can achieve a high personal status such as being a village, lineage, or war chief, a shaman, a person with special skills, or an economic or political leader (Fried 1967:82-89; Kent 1990:132-133; Means 1999:38; Service 1975:50-52). 
Even when the energy expenditure in constructing stone-chamber tombs suggests that an individual had relatively high status within his or her lifetime, that does not necessarily mean that the society was hierarchical. As was mentioned above, the number of grave goods recovered from Hageori is generally low. Indeed, one could certainly interpret Tomb Nos. 2 and 26, which have a few grave goods, as corresponding to high-status individuals. However, considering the quantity and quality of mortuary offerings deposited elsewhere in Korea (e.g., present-day Gyeongju, the capital of the Silla Kingdom), they are obviously insignificant. Most of the grave goods recovered at the site are utilitarian pots and mundane personal items. Thus, we need to be careful not to draw a hasty conclusion concerning social hierarchy by looking only at mortuary practices at the site.

Some Korean archaeologists have suggested that PCTs were used by groups with high social status, while ECTs were used by groups with lower social status because of the difference between the two in terms of both style and energy expenditure. This dichotomy, however, is not convincing. There is no doubt that people exerted a great deal of labor to erect PCTs. By taking a superficial look at the stone-chamber tombs in terms of energy expenditure, such differences as physical labor appear to be associated with vertical social position in the area under study. But they should not be regarded as criteria to argue for the adoption of a specific tomb type according to social status. Overall, a small group, working together, could have constructed these tombs without great effort.

Of greatest significance, there is no great difference between PCTs and ECTs in terms of energy expenditure (e.g., volume and size of a tomb and number, size, and quality of stone used to build both types of tombs). Furthermore, we should take into consideration the fact that some archaeologists have argued that large funerary structures do not necessarily imply the buried was a ruler or occupied a high post in the social hierarchy (Braun 1981:410-412; Goldstein 1981:55-56; O'Shea 1984:17-18; Ucko 1969:267-268). More important, the two different types of stone-chamber tombs are located in the same cemetery area. At the Hageori site, there is no geographical separation that has generally been considered an indicator of social status differentiation between groups (Chapman and Randsborg 1981:15; Peebles 1971:71, 73; Saxe 1970:160, 165166; Ucko 1969:267, 270). Thus, it is difficult to argue the presence of social ranking at the village based on the typological difference of the stone-chamber tombs.

Mortuary data recovered from the site demonstrates differential burial treatment. However, it only seems that there were some relative social status differences within the Hageori area. Indeed, we cannot rule out the possibility that certain stylistic differences in the stone-chamber tomb structures might have been caused by differential use or social roles. As will be discussed below, however, the differences, which include some small variations in tomb style, may have been related to temporal factors rather than to social status.

It is quite common to find similar stone-chamber tombs in such cemeteries built in the Baekje territory during the Three Kingdoms period (c. between the third and seventh century) in Korea. If we are taking into consideration a great deal of geographic and temporal variability in the material expressions of mortuary practices among the villages in the vicinity of Yeoju, some cultural differences reflected in funeral behavior in terms of both grave goods and energy expenditure 
can be ignored. The fact that many similar mortuary programs are found around the Yeoju area strongly suggests that stone-chamber tombs (i.e., both PCTs and ECTs) were common mortuary architecture at that time. That is, burial practices might have been similar among contemporary village communities.

In sum, there is a strong possibility that the stone-chamber tombs in the study area may have been the products of cooperative group labor among volunteers working under the supervision of an ad hoc leader or an elderly man of the burial society in the autonomous village. This funerary custom was widely practiced up until the end of the 1970s in rural areas of Korea. In fact, the underlying concept is still widely practiced by the majority of people in the "gye" (a mutual assistance association) of modern Korea.

\section{SUMMARY AND CONCLUSION}

It is generally believed by archaeologists that mortuary practices are one of the most conservative cultural behaviors in most societies. Nonetheless, a gradual change in mortuary customs was discerned at the Hageori site. The influence of Chinese culture and particularly the mortuary practices of Goguryeo have been regarded as one of the dominant factors in the change, though specific reasons are still not clearly known. The PCT, which has been regarded as a rather distinctive burial type, is believed to have originated in Goguryeo. It is widely accepted that this unique burial type spread to Baekje first and then from Baekje to Silla.

Changes in mortuary practices do not seem to correspond with changes in religious belief in the Baekje Kingdom. That is, during the reign of King Chimlieu (A.D. 384), Baekje adopted Buddhism from Eastern Jin, China (A.D. 317-419). However, a corresponding change in mortuary practices in Baekje has not been archaeologically identified so far. Therefore, one thing that needs to be kept in mind is that a change in religious belief did not play a key role in a change in mortuary customs in Baekje. Our sample size is too small to argue that any particular cultural factor influenced the change in mortuary ritual at the site.

The chronology for the PCTs excavated elsewhere in the Baekje territory has provided a good guideline for the determination of the date of burials at the Hageori site. There is a high possibility that the initial use of the stone-chamber tombs might even go back to the beginning of the fifth century, if not earlier. Consequently, as far as the identification of the ethnic group is concerned, I believe that the Baekje people were responsible for the construction of the stonechamber tombs. Although some Korean archaeologists have considered the Silla people to be the makers of the stone-chamber tombs at the site, it is difficult to accept their assertions.

No distinctive differences in terms of the quantity and the quality of grave goods and energy expenditure between PCTs and ECTs have been identified. The small variations detected in burial styles should not be considered to be archaeological criteria by which to judge the presence of vertical social status at the site. The difference between the two burial types in terms of both styles and energy expenditure might have been caused by temporal factors, and the ancient Hageori village seems to have remained an egalitarian society.

Although it is preliminary and far from conclusive, I hope that this assessment will shed some light on the study of mortuary data discovered in the Baekje 
territory in particular and in other regions of Korea as well. In order to better understand the comprehensive mortuary practices in Yeoju, we need to take into consideration mortuary behavior from a theoretical framework that incorporates all aspects of the Hageori village and all of Yeoju on a regional scale.

\section{REFERENCES CITED}

An, Seung Ju

1989 A study on vertically-dug stone-cists of Baekje. Journal of the Korean Archaeological Society 22:55-71 (in Korean).

BARnes, Gina L.

2001 State Formation in Korea: Historical and Archaeological Perspectives. Richmond, Surrey: Curzon Press.

BINFORD, LEWIS R.

1971 Mortuary practices: Their study and their potential, in Approaches to the Social Dimensions of Mortuary Practices: 6-29, ed. James A. Brown. Memoirs of the Society for American Archaeology, No. 25. Washington DC: Society for American Archaeology.

Braun, David P.

1981 A critique of some recent North American mortuary studies. American Antiquity 46:398416.

BROWN, JAMES A.

1981 The search for rank in prehistoric burials, in The Archaeology of Death: 25-37, ed. R. Chapman, I. Kinnes, and K. Randsborg. Cambridge: Cambridge University Press.

Carr, Christopher

1995 Mortuary practices: Their social, philosophical-religious, circumstantial, and physical determinants. Journal of Archaeological Method and Theory 2:105-200.

Chamsil Area Archaeological Team

1978 Archaeological report of Chamsil area. Journal of the Korean Archaeological Society 4:7-51 (in Korean).

Chapman, Robert

1995 Ten years after-megaliths, mortuary practices, and the territorial model, in Regional Approaches to Mortuary Analysis: 29-51, ed. L. Beck. New York: Plenum Press.

Chapman, Robert, and Klavs Randsborg

1981 Approaches to the archaeology of death, in The Archaeology of Death: 1-24, ed. R. Chapman, I. Kinnes, and K. Randsborg. Cambridge: Cambridge University Press.

Cho, Keun Woo

1994 A Study of Stone-Chamber Tombs in Chonnam Province. M.A. thesis. Department of Cultural Anthropology, Yeongnam University, Gyeongsan (in Korean).

Choi, Byeong Hyeon

1992 A Study on Silla Tombs. Seoul: Iljisa (in Korean).

Choi, Wan Kyu

1997 A Study on Baekje Tombs in the Geum River Area. Unpublished Ph.D. diss. Department of History, Soongsil University, Seoul (in Korean).

Choi, Young Hee, Jung Ki Kim, and Ki Ho Song

1988 Excavation Report on the Yonggangol Group of Tombs at Maeryongri, Yeoju, Gyeonggido, Korea: Archaeological Research Report of the Hallym University Museum, vol. 2. Hallym University Museum, Choonchun (in Korean).

1989 Excavation Report on the Yonggangol Group of Tombs at Maeryongri, Yeoju, Gyeonggido, Korea: Archaeological Research Report of the Hallym University Museum, vol. 3. Hallym University Museum, Choonchun (in Korean).

Fried, Morton H.

1967 The Evolution of Political Society: An Essay in Political Anthropology. New York: Random House. 
Goldstein, LynNe

1981 One-dimensional archaeology and multi-dimensional people: Spatial organisation and mortuary analysis, in The Archaeology of Death: 53-69, ed. R. Chapman, I. Kinnes, and K. Randsborg. Cambridge: Cambridge University Press.

HärKe, HeINRICH

2000 Social analysis of mortuary evidence in German Protohistoric Archaeology. Journal of Anthropological Archaeology 19:369-384.

Hong, Bo SiK

1992 A Study of the Stone-Chamber Tombs with a Side-Entrance in Yeongnam Region. M.A. thesis. Department of Archaeology, Busan University, Busan (in Korean).

IM, YOUNG JiN

1995 A Study on the Baekje Tombs of Hanseong Period. Unpublished Ph.D. diss. Department of Archaeology and Art History, Seoul National University, Seoul (in Korean).

KANG, HyeOn SuK

1996 On the transition of Baekje stone-chambered tomb. Journal of the Korean Archaeological Society 34:83-134 (in Korean).

KANG, IN Ku

1983 A Study of Baekje Tombs. Seoul: Iljisa (in Korean).

Kent, Susan

1990 A cross-cultural study of segmentation, and the use of space, in Domestic Architecture and the Use of Space: An Interdisciplinary Cross-cultural Study: 127-152, ed. S. Kent. Cambridge: Cambridge University Press.

Kim, Byeong Mo, Gwang Ju Sim, and Me Gyeong Huh

1986 The Field Survey of Cultural Remains of Baekje in Gyeonggi Province in Korea. The University Museum Research Series No. 3. Hanyang University, Seoul (in Korean).

Kim, KI WoONG

1976a Tombs of Baekje. Tokyo: Gakusaysya (in Japanese).

$1976 b$ Tombs of Silla. Tokyo: Gakusaysya (in Japanese).

KIM, WON YonG

1974 Tombs of Korea. Seoul: The Society for the Commemoration of King Sejong (in Korean).

1982 A few observations on Baekje tombs. Journal of Baekje Studies (special volume for the celebration of the 30th year of the opening of Choongnam University): 103-110 (in Korean).

1986 The Introduction to Korean Archaeology, 3rd ed. Seoul: Iljisa (in Korean).

1987 A Study of Korean Archaeology. Seoul: Iljisa (in Korean).

Means, Bernard K.

1999 Monongahela mortuary practices in Somerset County, Pennsylvania: Observations and implications. Pennsylvania Archaeologist 69(2): 15-44.

Nishitani, TADAShi

1981 Notes on Korean Archaeology. Tokyo: Gakuseisha (in Japanese).

O’SHEA, JoHN M.

1984 Mortuary Variability: An Archaeological Investigation. New York: Academic Press.

PARK, YEONG BOK

1995 Burial, Gongju area, in Archaeology of Baekje: 69-95, ed. Minjokmunhwasa Editorial Committee. Seoul: Minjokmunhwasa (in Korean).

Pearson, Richard, Jong Wook Lee, Won Yeong Koh, and Anne Underhill

1989 Social ranking in the Kingdom of Old Silla, Korea: Analysis of burials. Journal of Anthropological Archaeology 8:1-50.

Peebles, Christopher S.

1971 Moundville and surrounding sites: Some structural considerations of mortuary practices II, in Approaches to the Social Dimensions of Mortuary Practices: 68-91, ed. James A. Brown. Memoirs of the Society for American Archaeology, No. 25. Washington DC: Society for American Archaeology. 
Saxe, Arthur A.

1970 Social Dimensions of Mortuary Practices. Unpublished Ph.D. diss. Department of Anthropology, University of Michigan, Ann Arbor.

Service, Elman

1975 Origins of the State and Civilization: The Process of Cultural Evolution. New York: W. W. Norton \& Company.

Tainter, Joseph A.

1975 Social inference and mortuary practices: An experiment in numerical classification. World Archaeology $7: 1-15$.

1978 Mortuary practices and the study of prehistoric social systems. Advances in Archaeological Method and Theory $1: 105-141$.

UCKo, Peter J.

1969 Ethnography and archaeological interpretation of funerary remains. World Archaeology 1: $262-280$.

Yi, NAM SEOK

1992 A study on the origin and the content of stone-chamber tomb in Former Baekje. Prehistory and Ancient History 3:75-113 (in Korean).

1995 A Study of Baekje Stone-chamber Tomb. Seoul: Hakyeon Munhwasa (in Korean).

\begin{abstract}
Archaeological excavations conducted in 1997-1998 at the Hageori site in central Korea uncovered a total of 63 burials. The range of dates for the burials varies widely. Mortuary analysis was conducted on 24 burials thought to date sometime between the fifth and seventh century A.D. According to the archaeological data, mortuary practices at the site changed through time from multiple burials (in a sidepassage stone-chamber tomb) to single burials. This article describes the mortuary practices at the site and attempts to explain how and why they changed over time. Using archaeological data and a literature review, the ethnic group of the tomb builders is inferred. In addition, attention is given to examining the relationship between energy expenditure and social stratification based on stylistic variation of the burials discovered at the site. Keywords: Korea, archaeology, mortuary practices, chronology, ethnic group, social stratification.
\end{abstract}

